Volume $6 \quad$ Nomor 1, Juni 2018

Halaman $81-95$

\title{
STRATEGI RESPONS PUJIAN YANG DIGUNAKAN ORANG AMERIKA DAN ORANG BUGIS \\ (Strategies Used by Americans and Buginese in a Complimentary Respondent)
}

\author{
Mutmainnah Hasyari \\ Universitas Hasanuddin Makassar \\ Jl. Perintis Kemerdekaan Km. 10, Tamalanrea, Kota Makassar, Sulawesi Selatan \\ Pos-el: mutmainnah.hassyari1990@gmail.com
}

(Diterima: 20 April 2018; Direvisi: 13 Mei 2018; Disetujui: 3 Juni 2018)

\begin{abstract}
Americans and Buginese have the strategies to respond the compliment which are different from the theory that proposed by linguists. The aims of this research were (1) addressing types of strategies used by the Americans and Buginese to respond the compliments based on gender; and (2) disclosing the effect of complimentary responses in American and Buginese culture. The research data consist of English and Buginese language. Data on English language were taken from the you tube that contained the strategies used by Americans to respond the compliment, while Buginese data were gathered from the field by recording DCT questionnaire. Both types of data were analyzed by using descriptive qualitative. The result of research showed that (1) complimentary responded strategies used by American and Buginese were applying the complimentary responded category of Holmes (1988, 1993). Other wise, the types of the complimetary respond that used by Buginese, such as joke and social norm did not appeart in this theory. Both American males and females tended to respond the compliments by acceptance, while females Buginese tended to accept the compliments by showing solidarity between interlocutor and reject the compliment to avoid self-praise. Males Buginese tended to accept jokes not compliments in. (2) the exsistance of Culture played important roles to respond the compliments to nor the Americans orBuginese. The Americans responded the compliments with simple answers and accepted them as the princip of informality and equality. Buginese prefered to respond the compliments with other compliment or inferiority because they were leaning on the principle known as 'sipakatau', sipakalebbi', and 'sipakainge'.
\end{abstract}

Keywords: compliments, strategies, gender, culture

\begin{abstract}
Abstrak
Dalam merespons pujian, orang Amerika dan orang Bugis memiliki strategi yang berbeda dengan teori yang telah diusulkan para ahli. Penelitian ini bertujuan (1) menunjukkan jenis strategi yang digunakan oleh orang Amerika dan orang Bugis dalam merespons pujian berdasarkan jenis kelamin dan (2) mengungkapkan pengaruh budaya orang Amerika dan orang Bugis ketika merespons pujian. Data penelitian terdiri atas bahasa Inggris dan bahasa Bugis. Data bahasa Inggris diambil dari video youtube yang mengandung kalimat respons pujian oleh orang Amerika. Sementara data bahasa Bugis diambil dari lapangan melalui proses rekaman dan kuesioner DCT. Kedua data dianalisis menggunakan metode deskriptif kualitatif. Hasil dari penelitian ini menunjukkan bahwa (1) respons pujian oleh orang Amerika dan orang Bugis masih mengaplikasikan kategori respons pujian dari Holmes (1988, 1993) Namun, di sisi lain terdapat tipe respons pujian bahasa Bugis yang tidak dijelaskan dalam teori, yaitu tipe bergurau dan norma sosial. Baik laki-laki maupun perempuan Amerika lebih cenderung merespons pujian dengan tipe menerima, sedangkan perempuan Bugis lebih cenderung menerima untuk menunjukan solidaritas terhadap mitra tutur dan menolak pujian untuk menghindari sikap meninggikan diri. Sementara laki- laki Bugis cenderung bergurau daripada menerima pujian. Laki- laki Bugis juga cenderung menolak pujian. (2) Kehadiran budaya sangat berpengaruh dalam merespons pujian, baik oleh orang Amerika maupun orang Bugis. Orang Amerika merepons pujian dengan jawaban sederhana dan cenderung menerima pujian karena mereka berpegang pada prinsip informal dan kesetaraan, tetapi orang Bugis cenderung merespons pujian dengan kembali memuji atau dengan merendah diri karena mereka bersandar pada prinsip yang mereka sebut sipakatau, sipakalebbi,dan sipakainge.
\end{abstract}

Kata-kata kunci : pujian, strategi, jenis kelamin, budaya

\section{INTRODUCTION}

The term of a speech act is defined as an utterance as a functional unit in communication. According to Ziaei (2012), a speech act has two kinds of meaning: proposition or locution meaning 
and illocutionary meaning. For example, "The phone is ringing," the propositional meaning is what it says about the ringing of a telephone. The illocutionary meaning is what the speaker intends, for example, a request to answer the telephone. Furthermore, someone performs speech acts in offering an apology, greeting, request, complaint, invitation, compliment, or refusal. A speech act is also showed in utterance as in "Hey, I really like your tie!" to serve compliment or in sentence "you are very kind" to present a praise to someone. Speech acts include real- life interactions and require not only knowledge of the language but also appropriate use of that language within a given culture.

Compliment is one of the utterances that people often use in conversation through language. As mentioned earlier, compliment is one of speech acts which serve expression or positive evaluation that commonly occurs in everyday conversation encounters among the interlocutors. Holmes in $\mathrm{Wu}$ (2008), defined "A compliment is a speech act which explicitly or implicitly attributes credit to somebody other than the speaker, usually the person addressed, for some good (possession, characteristic, skill, etc.) which is positively valued by the speaker and the hearer". Compliment is often found in daily conversation within people in the society. A compliment may be used to open a conversation or to smooth conversational interaction by building up the links of solidarity among the interlocutors and as well as a compliments used to create a good social relationship. Someone used a compliment which relates to personal, appearance (e.g., clothes, hair), possessions, skill, or accomplishments. Knapp et al in Shahsavariaet al (2014), defined that Compliment responses mainly give back the social-cultural standards and varieties of certain speech communities.

Some previous researches were conducted related to issue of compliment response in some countries. The strategies of compliment response and some particular factors affecting compliment response such as age, gender, education, etc become the crucial issues in conducting research on compliment response. Lorenzo- Duzin Ebadi\& Salman (2015), examined a corpus consisting of a thousand compliment responses by British and Spanish male and female undergraduates. The results showed the existence of cross- cultural and crossgender similarities as well as difference among four groups of subject. For example, Spanish makes tended to upgrade compliments ironically (a type of compliment response absent in the British data) more frequently than their female counterparts.

Katsuta (2012), did research on compliment responses related to topic of compliment. His research investigated the role of compliment topic by analyzing compliment responses between Japanese and American college students. The result denoted that compliment responses can be seen as solutions for maintaining a balance between (1) a preference to avoid selfpraise and (2) a preference to accept or agree with the compliment. Building on studies showed that response strategies can be influenced by compliment content and context, the study analyzed responses to compliments on ability, achievement, belongings, appearance, and personal characteristic by determining the subject's choices of response strategy categorized as acceptance, avoidance, or rejection for each compliment topic.

$$
\text { Ibrahim \&Riyanto (2011), }
$$
compared the compliment response between American and Indonesian. Their research resulted that both of American and Indonesian have different and similar way of expressing responses to compliment. The difference might be due to the different cultural background. Although there were some similarities, the frequencies of each type could give a clear insight on the role of those different 
cultural backgrounds. Both the American and Indonesian respondents used ten types of compliment responses, eight of them were based on Herbert's categories, the others were the Indonesian respondent only. The eight types were Appreciation Token, Comment Acceptance, Praise Upgrade, Reassignment, Return, Scale down, and No Acknowledgment. The other two were promise and hope. Furthermore, the research found that the status became an important variable in giving response to compliments. Appreciation Token were used more by the Indonesian and American subordinates than by their superiors. On the other hand, Comment Acceptance were used more often by both the Indonesian and American superior.

Al- Falasi (2007) compared Arabic learners of English with English native speaker. His result showed that there was no difference culture in the use of compliment. The difference happened when it came to compliment responses. For instance, according to Ghawi (1993), in Arabic South Africa, English speakers more frequently accepted the compliment rather than rejected it. On the other hand, Asian non-native speakers of English prefered to reject the compliment, as they difficulted in responding appropriately the compliments.

Chen (1993), compared the compliment responses produced between American and Chinese. In his investigation, He used DCT (Discourse Completion Test) questionnaire to the respondents of his research to gain the objective of his investigation. His result found that Chinese used rejection, higher than the Americans. It is about 95.73\%.. On the other hand, the category of acceptance was only $4.4 \%$..

Based on that topic above, this research aimed to show various strategies of compliment response used by American and Buginese based on gender. Likewise, this research alsaimed to reveal the underlying culture's background related to varied topic of compliment.

\section{LITERATURE REVIEW}

This chapter deals with three parts. First, it concerns with brief reviews of some related studies previously conducted on compliment response. Second, it relates on the underlying concept that frames as well as some related ideas in this study. Third, it presents the theoretical framework which shows how the underlying concept in this study is related to the questions investigated in this research.

\section{A. PREVIOUS STUDIES}

A number of investigations as inspired by Herbert's extensive research on compliment response had been conducted comparing compliment responses. Daikuhara (1986), had collected 115 compliments of natural conversations by 50 native speakers of Japanese. His investigation found that Japanese doing compliment seem to serve the addresser's compliance to the recipients and this may madedistance between both interlocutors. In order to maintain harmony between them, the recipients tend to reject or deflect the compliment.

Chen (1993), compared the compliment responses produced between American and Chinese. In his investigation, He used DCT (Discourse Completion Test) questionnaire to the respondents of his research to gain the objective of his investigation. He found that Chinese used rejection higher than the Americans. It is about $95.73 \%$. On the other hand, the category of acceptance was only $4.4 \%$ from the compliment responses.

Later on, Gajaseni (1994), had compared the compliment responses produced by American and Thais. He used Discourse Completion Test (DCT), the same methodology which was used by Chen (1993). He conducted an analysis of 
different compliment response types which consist of acceptance, rejection, and indirection. The result of his study denoted that the Americans used acceptance type responses significantly more frequent than the Thais.

Nelson et al., (1996), had investigated compliment response concern to gender. They analyzed the similarities and differences of compliment responses between the Egyptians and the American by interview sessions. One of the purposes of the research was concerning the gender of the compliment giver and the recipients. His respondents were 20 American students and 20 Egyptian students; which all of them were men and women students. The result indicated that their patterns of compliments were similar primary adjectival and it was being the reason for the positive meaning. Besides that, the study furthermore showed that the Americans produced compliments more commonly as to the Egyptians.

The similar research also investigated by Ibrahim and Riyanto (2000). They compared compliment response between American and Indonesian. Their research resulted that both of American and Indonesian have different and similar way of expressing responses to compliment. The difference may be due to the different cultural background. Although there were some similarities, the frequencies of each type could give a clear insight on the role of those different cultural backgrounds. Both the American and Indonesian respondents used ten types of compliment responses, eight of which were based on Herbert's categories, the others were used by the Indonesian respondent only. The eight types were Appreciation Token, Comment Acceptance, Praise Upgrade, Reassignment, Return, Scale down, and No Acknowledgment. The other two were promise and hope. Furthermore, the research found that the status became an important variable in giving response to compliments. Appreciation Token was used more by the Indonesian and American subordinates than by their superiors. On the other hand, Comment Acceptance were used more often by both the Indonesian and American superior.

Lorenzo- Duz (2001), had examined a corpus consisting of a thousand compliment responses by British and Spanish male and female undergraduates. The results showed the existence of cross- cultural and crossgender similarities as well as difference among four groups of subject. For example, Spanish tended to upgrade compliments ironically (a type of compliment response absent in the British data) more frequently than their female counterparts (Ebadi and Salman, 2015).

Hiba Qusay Abdul Satar and Salasiah Che Lah (2009), had investigated a research concern to compliment responses in English among Iraqi Postgraduate at University Sains Malaysia (USM). He attempted to show whether the respondent will produce compliment response in the same time with pragmatic transfer process. Their research resulted that this certain group had adapted differences types of compliment responses. Definitely pragmatic transfer was existed in compliment responses produced by the respondent. Both researchers concluded this might happens due to the respondent's lack of knowledge of different sociolinguistic rules among cultures. Besides that, it could also because of the respondents' dependence on their mother tongue sociolinguistic norm in presenting speech act in the target language.

A research under the title "The Role of Compliment Topic and Compliment Response" was conducted by Katsuta (2012). His study investigated the role of compliment topic by analyzing compliment responses between Japanase and American college students. The result denoted that compliment responses can be seen as solutions for maintaining a balance between (1) a preference to avoid selfpraise and (2) a preference to accept or 
agree with the compliment. Building on studies showing that response strategies can be influenced by compliment content and context, the study analyzed responses to compliments on ability, achievement, belongings, appearance, and personal characteristic by determining the subject's choices of response strategy categorized as acceptance, avoidance, or rejection for each compliment topic.

It can be seen that the number of researches or investigations done on compliment and compliment responses. Though, none of them was associated and compared it with local language especially in Buginese language in Pinrang Regency and based on gender. Hence, this research attempts to study the comparison of the Buginese and Americans' responses to compliments. The researcher will focus on the strategies of compliment response from two groups in term of their gender. On top on that, this research will aim at inferring the respondent's perspective behind the culture's backgrounds of choosing certain types of compliment response by virtue of the topic compliment response.

\section{THEORETICAL BACKGROUND}

The term of speech community should be advanced. One of the researcher denoted that a speech community is a group of people who attribute a set of norms about the use of a language or languages (Gumperz in Chaika, 1994: 309). Meantime, Fishman (1972), assigned the definition of a speech community is all members or group of people who serve a single of variety and it'snorms appropriately. Summarily, it can be concluded that a speech community is a group of speakers which share a single speech variety and has the same rule for speaking. In addition, Labov's in Wardaugh, 1998 defined of speech is not symbolyzed by any agreement of language elements. Likewise the participation in a set of shared norms. These norms are recognized by the types of evaluative behavior and the uninformity of abstract patterns of variation respect to certain levels of usage. Basically, a speech community must at least share rules for speaking because members of a speech community may not use the rules of language in the same way.

Sociolinguistically, Language and human kind are related to each other. As one of important things in communication, language is used by society to interact with others. The study of relationship between language and society is called sociolinguistics. Several scholars describe sociolinguistics such as, Hymes (1974: vii) defined sociolinguistic connected between laguage and society with the aim to make a better understanding of the structure of language and the function of laguage and the function language in communication. Additionally, William Downes (1984: 15) defined sociolinguistics as the part of linguistic which studies about properties of language and languages which require reference to social, including contextual factors on their explanation. Summarily, sociolinguistics concerned with the use of language in relation to social dimension that involves the social relationships of social community. It means that sociolinguistics is connected with the way people use language when they interact each other so that it can be seen what the language patterns are and how they are used in any situation of communication. Therefore, investigating the way people use language in different social contexts results a great of information about the way language applies, as well as relate to the social relationships in any community.

Thomas (1995: 22) had defined the term of pragmatics as meaning in interaction. He emphasized that meaning is not something which inherent in the words alone, nor is it produced by the speaker neither the hearer. It means that there is a changing process including the negotiation of meaning between speaker and hearer, the context of utterance (physical, social, 
or linguistic) and the meaning potential of one utterance. Furthermore, Yule (1996) defined that the term of pragmatics studied about contextual meaning. This type of study includes the interpretation of the way people mean in a certain context and how the context affects of what is said. It also needs a consideration with who they are talking to, where, and in what circumstances. Thus, the benefit of studying language in pragmatics are understanding people's intended meaning, their assumptions, their aims or goals, and kind of actions that they performwhen they speak to the interlocutor.

Basically, as Holmes (1992), said that language has two purposes; referential and affective. It denoted objective information of a referential kind and it can also express the feeling of someone. As an interlocutor, in conveying something on his or her mind, one has to make sure that the aim of the sentences that being used are relevant with interpretations and perceptions about the roles of the sentences themselves. This is one of the comprehensions that making appropriate compliment response from one person to another is important. Holmes (1992) denoted that social factors have an important role in the use of language in human interaction. For some reasons, emphasis will be given to the users of the language, while others will concern with its uses which are the social setting and function of interaction. In particular situations, the speakers and the recipients are important factors that need to be allowed for, whereas in other situations, the essential aspect is the setting or the social context. Additionally, the objective of the communication maybe important, while in other circumstances, the topic has a control over the choice of language being used in a conversation.

Wu in 2008, concluded six types of compliment based on its' function, they were; a) To show admiration or approval of someone's work/ appearance/ taste (Herbert, 1986).

Example: I like your hat

This kind of compliment only make a compliment to someone appearance and show the speaker's admiration.

b) To establishconfirm/maintain solidarity (Wolfson, 1989). When a stranger comes into a group and makes the utterance in example above, it also can be regarded as a method to establish a new friendly relationship in the group.

c) To replace greetings/gratitude/ apologies/congratulations

(Wolfson. 1983). When two friends meet with each other, one of them utters a sentence like;

Example: How are you today!

This utterance has the same function of the greeting as "How are you?"

d) To soften face threatening act such as apologies, requests and criticism (Wolfson, 1983), if the speaker makes some offence to the hearer. He can use a compliment to change the topic and soften the tense atmosphere.

e) To open and sustain conversation or conversation strategy (Wolfson. 1989). If the interlocutors are strangers, they can begin their conversation from the compliments to open the dialogues. It describes in example below;

Example :Hi, your English is very good, when did you begin to learn it?

f) To reinforce desired behavior (Manes, 1981). It is usual in daily life.

Example: "How nice your ear rings are!" "Where did you buy them?"

Investigation through the topic and structure of compliments has been done by 
Knapp et al., (1984). He denoted that most compliments are given to interlocutor or to the recipients of the same age and social status. On top of that, according to Herbert (1989), in American English, Agreement responses happen just about one third of the time and generally. Major compliment topics can be classified into three categories based on objet of compliments; appearance/pessesions,

performance/skill/abilities, and personality traits (Manes \&Wolfson, 1981, Knapp et al., 1984, Wolfson, 1989, Herbert, 1998).

Compliments in certain situations have different meanings and functions. Basically, they usually use as a politeness strategy to make other feel comfortable and maintain the conversation. Talking about the compliments in Asians countries, as stated by Kartomihardjo (1978), a speaker tend to be careful in performing compliments to someon. As Asian people, compliments are not quite general. According to his perspective, a close relationship between the speaker and the recipient is an important condition before compliment is expressed. The closer relationship both of them possess, the more openness they have in stating their compliments to one and another.

\section{Longman Dictionary of \\ Contemporary English (2004),}

Compliments are very important speech act and cooperative strategy in humans live. It has three kinds of meanings namely to express admiration of someone or something, to show that we trust someone else and have a good opinion of them, to express praise, or good wishes (Wu, 2008).

In the free dictionary (2008), compliments have the same meaning: they can be expressions of praise, admiration, or congratulation; they can be formal act of civility, courtesy, or respect; or they can be good wishes; regards ( $\mathrm{Wu}, 2008)$. Some researchers have made some definitions about compliments, Among the famous and standard one is Holmes' version:
A compliment is a speech act which explicitly or implicitly attributes credit to someone other than the speaker, usually the person addressed, for some 'good' (possession, characteristic, skill, etc) which is positively valued by the speaker and the hearer (1986: 485)

From the descriptions before, it is easy to see some principles that define compliments: it is a polite speech act, it can be direct or indirect, which means it can has an explicit form meaning that people can distinguish it quickly, or it can has not an obvious structure. However, people still regard it as a compliment, only if it can attribute credit to someone according to its implicit meaning, and the last, it is given to others, not to the speakers themselves.

Pomerantz (1978) was the first researcher who studied the compliment responses. In her research finding, she denoted that, in American English, the addressee of a compliment faces two (2) contradiction conditions which pose a tight spot when responding it; (A) Agree to the speaker, and (B) Avoid self- praise. For instance, the addressee agrees with| the addresser by accepting the compliment praise (condition A), it breaks condition B in that the response goes against the speaker's sociolinguistic expectations. However, when the addressee does not agree to the compliment in order to follow condition $\mathrm{B}$, the response can be considered as face- threatening since it breaks condition $\mathrm{A}$ the addressee of the compliment implements a variety of solutions to overcome this clash, categorized by Pomerantz as (1) Acceptance, (2) Rejection, (3) Self- praise Avoidance.

Leech (1983) showed his compliment response research by recognized model of politeness. He stated that one way for speakers to breach conversational principles is to be polite. Hence, he proposed six maxims to account for a variety of response compliments, such as accepting, returning, mitigating, 


\begin{tabular}{|c|c|c|}
\hline $\begin{array}{c}\text { Macro } \\
\text { level of } \\
\text { CRs }\end{array}$ & $\begin{array}{c}\text { Micro level of } \\
\text { CRs }\end{array}$ & Examples \\
\hline Accept & $\begin{array}{l}\text { - Appreciation } \\
\text { token } \\
\text { - Agreeing } \\
\text { utterance } \\
\text { - Downgrading } \\
\text { - Return } \\
\text { Compliment }\end{array}$ & 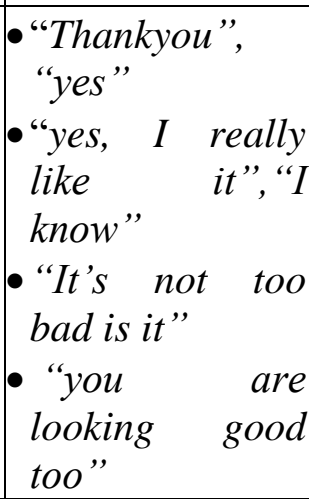 \\
\hline Reject & $\begin{array}{l}\text { - Disagreeing } \\
\text { utterance } \\
\text { - Question } \\
\text { accuracy } \\
\text { - Challenge } \\
\text { sincerity } \\
\end{array}$ & $\begin{array}{l}\text { - "No, it was } \\
\text { good" "Really?" } \\
\text { - "Don't lie"" }\end{array}$ \\
\hline Avoid & $\begin{array}{l}\text { - Shift Credit } \\
\text { - Invormative } \\
\text { Comment } \\
\text { - Request } \\
\text { reassurance }\end{array}$ & $\begin{array}{lr}\text { - "My mother } \\
\text { "knitted it". } \\
\text { - "It was } & \text { not } \\
\text { hard" } & \\
\text { - "Dorrr you } & \text { really think } \\
\text { so?", } & \end{array}$ \\
\hline
\end{tabular}

and rejecting, by the application of one or more than one maxim. For instance, accepting compliment can be considered as adherence to agreement maxim; returning compliments can be seen as an application of the Agreement Maxim and the Approbation Maxim; offering object of compliment or help as application of the Agreement Maxim; deflecting a compromising strategy between the needs to sticks onto the agreement Maxim and the Modesty Maxim; and rejection as Adherence to the Modesty maxim.

Brown and Levinson (1987) also proposed model of politeness in western context, accepting compliment shows the addressee's face wants because the former anoints the face of the recipients to be approved and liked. Still, the model which proposed by them cannot clarify the implementation of other kinds of strategies, such as returning, or deflecting by English speakers (Holmes, 1988) or the primary use of the rejecting by the Mandarin interlocutors (Chen, 1993).

After analyzing American English speaker's compliment responses, Herbert (1986) reform Pomerantz's taxonomy. Within 3 years, he collected more than a thousand samples of compliment responses of the American college students.

Similar findings are provided by Holmes (1988). Holmes believes that "a compliment not only makes a positive assertion, it also attributes credit to the addressee in relation to that assertion" (492). Based on this assumption, she developed three categories of compliment responses.

Holmes' (1988, 1993) taxonomy of CR strategies

Humans can be categorized into male and female in terms of biological sex. It is looked from their sex organs and genes. Besides that, by using gender to divide humans, it can be adopted a psychological and cultural term which involves the subjective feelings of maleness and femaleness. Meanwhile, gender also refers to society's evaluation of behavior as masculine or feminine (Basow et al., 1992). There are differences between women's and men's voices that have been studied from some aspects. In terms of biological aspects, men and women have the different physical vocal tract, therefore, the voice of women is various from men. For example, on the pitch, women usually speak with a high pitch because women have short and thin vocal folds while men speak at a low pitch (Graddol\& Swann, 1989:15).

There are differences between women's and men's voices have been studied from some aspects. In terms of biological aspects, men and women have the different physical vocal tract, therefore, the voice of women is various from men. For example, on the pitch, women usually speak with a high pitch because women 
have short and thin vocal folds while men speak at a low pitch (Graddol\& Swann, 1989:15). Spender's view in terms of social aspect of voice, mentioned that there were differences between women and men. Men usually use lower pitched voice not only because the anatomy but also their will to use the low pitched voice (Graddol\& Swann: 1989:18). For men, using the high pitched voices will be regarded as ridicule which will destroy their images. The lower pitched voices are regarded as more confident and dominant than higher pitched ones in men's opinions. In society, men are usually the authoritative group. They are the center of the society and the dominance while women are usually the subordinate groups in the society. bSome differences between men and women in speech act have been found (Coupland, 2000);

a. Women are more socially
engaged cooperative and
constructive than men;
b. Women are more silent than men in public, so they are a muted group;

c. Women ask more questions than men in speech pattern;

d. Women are interrupted more than men;

e. Women have different choices and frequency of the lexical items from men;

f. Women use more politeness behaviors than men.

\section{METHODOLOGY}

\section{A. Research Design}

This research aimed to find out the strategy in responding the compliment in American and Buginese. The researcher used two sources of data which were American compliment responses that was found inyou tube video and Buginese compliment response carried out by speakers in the field of social situation and Discourse Completion Test (DCT). The writer applyedqualitative descriptive method. According to Sugiyono (2010), the purpose of the research wasobtaining an accurate profile of the people, events or situations. So it guided the researcher to explore the data in comprehensive, extensive and deep waysThrough this research, the writer finally analyzed the data andexplained explicitly the strategies of compliment response that used by American and Buginese based on gender.

\section{B. Source of Data}

There were two kinds of data in this research. The first data was American data. It was gained by the conversation of the Americans in video youtube.com. All videos related to the compliment responses which had been downloaded. The second data was Buginese data. It was gathered by using a Discourse Completion Test. DCT questionnaire according to Blum- Kulka in Duan (2011), is designed to get compliments response patterns of the participants in the questionnaire. It was carried on to draw out compliment responses based on the topic of compliment. Besides that, the Buginese data was also gained by recording. The researcher did recording earlier. The researcher was recorded the dialogue which contained of compliments response naturally. Therefore, in this research, the analyzed data were the data that was gained from a DCT of the questionnaire and observation.

\section{Procedures of Collecting Data}

In collecting data, first of all, in Buginese data, the researcher dealt out a questionnaire to the participants. In this step, the researcher applyed a DCT and recording to draw out data which was related to this research. Meanwhile, the American data was gained by downloaded all conversation videos dealt with compliment response in video youtube.com. Then it was transcribed. The topic of compliment should be equal in order to make iteasy to be analyzed and 
compared both of the data by the researcher.

\section{Technique of Analyzing Data}

In technique of analyzing data, the researcher used some techniques in order to answer the research questions in the first chapter. First, the collected data were categorized into three types based on Holmes in Sadeghi\&Zarei (2013), Compliment Responses; Accept, Reject and Avoid. Second, the identified data were compared to show the difference strategies between American and Buginese. Last, the culture that influences both of groups were identified related to the response when they pay a compliment.

\section{FINDINGS AND DISCUSSIONS}

According to this research, the result revealed that American in responding the compliment still applyed the type of compliment response proposed in the theory. However, on the other hand, there were two types of Buginese compliment response uncovered by theory. They were joke and social norm and theothersthatcharacterized as Accept (appreciation token, agreeing utterance, downgrading and returning compliment), avoid (shift credit, informative comment, request reassurance) and reject (disagreeing utterance, question accuracy, challenge sincerity) which have been covered by the theory.

This part presented the strategies of compliment response that used by the speakers of Americans and Buginese people. The findings of the research were presented in some of tables based on Holmes' classification in compliment response. Each of the table shows the response of speakers and classifies them based on the speaker's perspective (acceptance, avoidance or rejection)in obviously different topic (appearance, possessions, ability and personality traits).

The responses of compliment in this research were categorized based on
Holmes (1988, 1993) taxonomy. Chen (1993) noted that Holme's taxonomy reflected the insight Pomerantz's (1978) constraints: the need to agree with the complementer motivated the acceptance of a compliment, the need to avoid self-praise motivated the rejection of a compliment, and the need to strike a balance between the two constraints led to the utterances that mitigated the compliment by avoiding it.

The data presented the compliment responses by female and male Buginese speakers which were collected by Discourse Completion Test (DCT) questionnaire.There were some various data of compliment response that were obtained by the writer. The data were taken from Buginese society in Pinrang. There were various responses that found in the data. The first datum was the participant who were involving in the male's response to female complementer with possession topic of compliment such as, "de', anu masempo iye e (no, it's cheap)". The next datum was the same kind of participant but different topic. The topic was appearance topic of compliment. From the six participants, most of them avoid the compliment as well with the general response "malebbi pi pute ta' na iya' (You are brighter than me)". These responses showed that the participants tended to avoid the compliment in informative comment. It was based on Holmes' (1988, 1993) taxonomy of compliment response strategies in avoiding and its micro level was informative comment. In this datum, the participants was the male who gave response toward another male as complimenter. His response was " $\mathrm{mmm}$, maccobi- cobi mo tu, Sappo (you' re kidding me,Bro)" . This response tended to accept the compliment in agreeing utterance, return compliment and joke. Agreeing utterance and return compliment was based on Holmes' (1988, 1993) taxonomy, but joke was not find in Holmes (1988, 1993) taxonomy and it's 
also less in frequently used by American. The next datum was the female participant who gave response to male who delivered compliment or as complimenter. The topic of this compliment was personality traits. her response to the compliment was "makanja tongeng ga? (do you think so?)". They responsed the compliment by using avoid strategy. The other datum was the female participant who gave respons toward another female who as complimenter. The topic of the compliment was ability. The female participant's response was "de'to namakanja ladda bateku (I didn't do it well)". Her response tended to reject the compliment that was given to her. This response was based on Holmes (1988, 1993) taxonomy. These Bugiese data showed that the Buginese responses which were uttered by female and male were appearance, possessions, ability and personality traits of topic compliment. In Buginese data the result showed varied responses. A number of data followed the Holmes taxonomy of compliment and some of them were not. Such as, when Buginese responsed the compliment by joking which it wasnot existed in Holmes taxonomy. While Americans in responding the compliment had their own ways. It could be looked on the data. The first datum was between male (recipient of compliment) and female (complimenter). The topic of compliment was appearance. The response of this datum was "yeah, thank you". The next datum was about possession topic of compliment. This utterance was uttered by male (recipent of compliment) and another male (complimenter). His response showed the acceptanece as "humm, thanks". The next one was between female and male in ability topic of compliment. The response when she got a compliment from another male was "smiling and nodding" which indicated acceptance response. The datum about personality traits topic of compliment that the researcher found was "ouh, it's very ice of you to say so, thank you”. It showed the acceptance response as well. Based on the American data, in responding to compliment, American tend to accept the compliment rather than rejected or avoid. The way they response the compliment was based on Holmes taxonomy of compliment response. Once, in some case, they avoided or rejected the compliment as the researcher found " $n o, I$ don't think so" or avoiding "you really think so?". But it was less rejection frequently rather than accepting the compliment.

A compliment is a speech act which explicitly or implicitly attributes credit to someone other than the speaker, usually the person addressed, for some 'good' (possession, characteristic, skill, etc) which is positively valued by the speaker and the hearer ( Holmes' , 1986: 485). Compliment response is a verbal acknowledgement that the recipients of the compliment hear and react to the compliment (Nelson et al., 1996).

Holmes developed three categories of compliment responses; accept, reject and avoid. In acceptance, there were four micro levels, they were appreciation token, agreeing utterance, downgrading utterance and returning compliment. In rejection, there were three micro levels, they were disagreeing utterance, challenge sincerity and question accuracy. In avoidance, there were three micro level, they were shift credit, informative comment and request reassurance.

Both American and Buginese data were analysed based on Holmes' compliment response categories. The result of this research showed that both of speakers Buginese and American used three types of compliment responses; accept, avoid and reject. The response types between two groups were varied. According to Holmes (1988), American tended to response the compliment with simple way such as "thank you" to accept the compliment, or "no, thanks" to reject the compliment. But in Buginese, most of 
them used various responses either in acceptance, avoid or reject the compliment. A unique response which was delivered by Buginese when they were got praised or compliment by their interlocutor. Those responses were joke and social norms. These responses did not exist in Holmes taxonomy of compliment response categories. Buginese used joke response when they tried to accept the compliment but they did not want to be considered as a self - praise, therefore, they preferred to use joke. It could be seen in this data, the compliment was "makanja ladde' presntasi ta, de' na sala ko runtu'ki nilai matanre (good presentation, you deserve to get a good mark)" The response was 'hum, maccobi- cobi mo tu' bro (you are kidding me, Man)". Buginese tended to use this response in topic compliment of appearance.

Besides that, Buginese also responded the compliment which related to social norms. This response occurred mostly in personality traits topic compliment. It could be seen in the data, "you are very good boy/girl, we do not know how to thanks to you". The response was "de' to na marigaga to pada sitolong memang satu pada tta rupa tau (it's ok, we help each other). Buginese tended to use this response excessively in personality traits.

When Buginese Male got compliment from another Male, they tended to reject the compliment in topic of compliment possession. They rejected the compliment by using disagreeing utterance type. In topic of appearance, male tended to avoid the compliment. They avoided the compliment by using shift credit type. In topic of ablity, male tended to accept the compliment. They accepted the response by using return compliment type. In topic of personality traits, male tended to accept the compliment. They accept the compliment by using social norm type. When Buginese Male got compliment from female, they tended to reject the compliment in possession topic of compliment. They rejected the compliment by using disagreeing utterance type. In appearance topic of compliment, male tended to avoid the compliment. They avoided the compliment by using shift credit type. In ability topic of compliment, male tended to accept the compliment. In personality traits topic of compliment, male tended to accept the compliment. When female Buginese got compliment from male, they tended to accept the compliment in possession topic of compliment. In appearance topic of compliment, female tended to accept the compliment. In ability topic of compliment female tended to avoid the compliment. In personality traits, male tended to accept the compliment. When female Buginese got compliment from another female, they tended to accept the compliment in possession topic. In appearance topic of compliment, female tended to avoid the compliment. In ability topic, female tended to accept the compliment. In personality traits topic of compliment, female tended to accept the compliment. Different with Buginese, Female and Male Americans tended to accept the compliment almost in every topics of compliment. It based on the other compliment response by the other researchers in the past few years. American tended to accept the compliment and gave simple response. It could be seen in the data, "hi Josh, nice beard", and the response was "oh, thanks".

In the east culture, especially in Buginese, had different way in responding the compliment. Most of them responsed the compliment with rejection or avoided to give respectful or modesty responses and to minimized the praise which was given to them. Rejection responses by Buginese didn't mean that they disrespectedthe speaker or the one who gave compliment. It showed that Buginese had his/her own way to response the compliment and to honor the speaker.

The influence of culture is significantly affected the response of the 
compliment which was delivered by two groups (American and Buginese). In The exploration of Buginese ancestor revealed some philosophy or value as a basic of Buginese culture. It was bequeathed from one generation to the next generation. They were bequeathed by advising or giving them messages. In Buginese, it was called pasang. In doing social interaction, Buginese always hold on to message of sipakatau, sipakalebbi, and sipakainge or 3S. These three messages influence theirconversation cultural. Sipakatau means that we as human have to respect each other in any conditions without looking their position. Nowadays, the culture was found rarely in the society of Buginese. Sipakalebbi means that we have to give appreciate to other people. We have to give praise to someone who has excesses. Sipakainge' means we have to remain each other to build a good relation. Otherwise, American had a different culture and value with east culture especially in Buginese. American culture differed with Buginese which Buginese always pay attention with the politeness, the face and the feeling of the interlocutor. Americans didn't pay attention of that. Americans who lean on equality value believed that everyone is created equal and has the same rights. This valued was included women as well as men of all ethnic and cultural groups. Therefore in this research, either male or female American in responding the compliment they tended to response the compliment by simple response such as "thanks", "thank you" or "yes". It could be seen in the data 81: "wow, you are great skier" and the response is "thanks". Besides that, Americans also lean on informality value. It means that American lifestyle is generally casual, informal and friendly. In sum up, every country had unique strategies in responding the compliment. It depended on what the background culture they have whom they speak with and what the conditionin.

\section{CONCLUSIONS AND SUGGESTION}

According to previous findings and discussions, the researcher drew some conclusions. First, data of American compliment responses completely worked with the categories of compliment response that proposed by the theory. On the other side, the types of compliment responses in Buginese data were also realized by the category of compliment responses. However, there were some types of compliment responses uncovered by the theory. They were about joke and social norms. Second, data of American showed that there was no difference response strategies between female and male when theyresponsed the compliment. Both of them used simple response and they tended to accept the compliment in every topic of compliment. Meanwhile, Buginese female and male used difference strategies in responding the compliment. Last, the culture of two groups was very affect in responding the compliment. American tended to accept and respond the compliment by using simple way because they leant on their culture which was equality and informality. Meanwhile, Buginese leant on their own culture which called sipakatau, sipakalebbi, and sipakainge'. Based on the research finding above, there were several points thatcould be recommended to the reader such as; first,responsed the compliment should properly use according to the situation and background of culture. It actually should not use freely. Second, the readers should have good comprehension in analysing context. At last, for the next researchers who want to study about compliment response, they can explore more detail about compliment response especially in other variables such usage, education, and etc.

\section{BIBLIOGRAPHY}

Al- Falasi H. 2007. "Just Say Thank You: A Study of Compliment 
Totobuang, Vol. 6, No. 1, Juni 2018: 81—95

Responses." The Linguistic Journal, 2 (1): 28--42.

Chen R. 1993. "Responding to Compliments: A Contrastive Study of Politeness Strategies between American English and Chinese Speakers". Journal of Pragmatics, 20:49--75.

Basowet al.1992. Gender, $3^{\text {rd }}$ edtion. USA: Brooks/ Cole Publishing Company.

Brown,P\& Levinson, S. 1987. Politeness: Some Universals in Language Usage. Cambridge: Cambridge University Press.

Duan Y. 2011. A Pragmatic Research Report on Compliment Speech Act. Finland: Academy Publishers.

Ebadi\& Salman. 2015. "Using Compliment Responses in Arabic and English: Focusing on Male and Female EFL Learners in Iraq." Journal of Applied Linguistic and Language Research, 2 (7): 157178.

Fishman,J. A. 1972. The Sociology of

Language. Massachusetts:

Newbury House Publishers

Gajaseni,C. 1994. A contrastive study of compliment responses in American English and Thai including the effect of gender and social status.

Dissertation.University of Illinois at Urbana- Champaign.

Ghawi M. 1993. "Pragmatic Transfer in Arabic Learners of English." Journal of Pragmatics, 1 (1): 39-52.

Graddol, D. \& Swann, J. 1989. Gender Voices. Oxford: Brazil Blackwell.

Herbert, R.K. 1986. Ay "Say Thank You" - Or Something, American Speech, 61, 76--88.

Hiba. Q. \&Salasiah C. 2009. A study of Compliment Responses in English among Iraqi Postgraduates. USM.

Holmes J. 1988. "Paying Compliments: A Sex- Preferential Politeness Strategy." Journal of Pragmatics, 12 (4): 445--465.
Hymes, D. H. 1974. Foundations in

Sociolinguistics: An Ethnographic

Approach. Philadelphia: University of Pennsylvania Press.

Ibrahim \&Riyanto T. 2011. "A Sociolinguistic Study of

Compliment Responses Among Americans and Indonesians and Its Implications for Teaching English.” $K @$ ta, 2 (1): 21-30.

Katsuta H. 2012. The role of Compliment Response (Dissertation and Theses). Japan: Portland State University.

Leech, G. N. 1983. Principles of Pragmatics. New York: Longman Group Limited

Lorenzo- Dus. 2001. "Compliment response among British and Spanish University students: a contrastive Study", Journal Pragmatics, 33, 107--127.

Nelson,G. et al. 1996. "Arabic and English compliment responses: potential for pragmatic failure." Applied Linguistics, 17(4), 411--432.

Pomerantz, A. 1978. "Compliment Responses, Notes on The CoOperation of Multiple Constraints", in Schenkein, J. (ed.), Studies in the Organization of Conversational Interaction, pp.79--112, London: Academic Press.

Sadeghi \& Zarei. 2013. Investigating the Use of Compliments in Persian and English: A Case Study of Iranian EFL Students. Journal of Foreign Language Teaching and Translation Studies, 2 (2): 30--49.

Shahsavaria. et al. 2014. "Compliment Responses: A Comparative Study of Native English Speakers and Iranian L2 Speakers". Journal of Pragmatics, 98 (1): 1745--1753.

Sugiyono. 2010. Penelitian Kuantitatif, Kualitatif dan $R$ \& $D$. Bandung: Penerbit Alfabeta.

Thomas, J. 1995. Meaning in Interaction: an Introduction to Sociolinguistic, 
fifth edition. Massachussetts: Blackwell Publishing Ltd.

Wardhaugh, R. 1998. An Introduction to Sociolinguistics, fifth edition. Massachusetts: Blackwell Publishing Ltd.

Wu L. 2008. Gender-Based Differences in compliments (Elective Course: Language and Gender). Sweden: Kristiantad University.
Yule, G. 1996. Pragmatics. New York: Oxford University Press

Ziaei N. 2012. "Translation on the Basis of Frequency: Compliment and Compliment Responses". Translation Journal, 16 (3): 40-55. Retrieved on May $18^{\text {th }}, 2016$. Available from http://translationjournal.net/journal 61compliment.htm 